\title{
Pembelajaran Tahfidz sebagai Media Menumbuhkan Karakter Tanggung Jawab pada Anak Temper Tantrum
}

\author{
Monita Nur Shabrina ${ }^{\circledR}$, Nur Azizah², Muhammad Zuhad Rifqi ${ }^{3}$ \\ Pendidikan Anak Usia Dini, Universitas Negeri Yogyakarta ${ }^{1}$ \\ Pendidikan Luar Biasa, Universitas Negeri Yogyakarta ${ }^{2}$ \\ Pendidikan Ilmu Pengetahuan Sosial, Universitas Negeri Yogyakarta ${ }^{3}$ \\ DOI: $10.31004 /$ obsesi.v4i2.511
}

\begin{abstract}
Abstrak
Tanggung jawab merupakan karakter penting yang harus dimiliki oleh setiap individu, tidak terkecuali anak berkebutuhan khusus. Pendidikan karaker tanggung jawab pada anak berkebutuhan khusus dapat dilakukan dengan pemilihan metode pembelajaran yang tepat. Tujuan penelitian ini untuk mengetahui bagaimana cara yang digunakan untuk menumbuhkan karakter tanggung jawab pada anak temper trantrum dalam pembelajaran Tahfidz di Yayasan Islam Ar-Ruhama Kabupaten Kuningan. Penelitian ini merupakan penelitian kualitatif. Pengumpulan data dilakukan melalui observasi, dokumen, dan wawancara. Analisis data dilakukan dengan menarik tema. Hasil penelitian menunjukan bahwa pengembangan karakter tanggung jawab untuk anak dengan temper trantrum dalam pembelajaran Tahfidz dilakukan dengan rutinitas pembelajaran tahfidz, diberikannya tugas mandiri, adanya daftar ceklist (mutaba'ah), diberikan kesempatan memimpin, dan adanya bintang prestasi sebagai reward.
\end{abstract}

Kata kunci: temper tantrum; tanggung jawab; pembelajaran tahfidz.

\begin{abstract}
Everyone, including children with special needs, is supposed to possess characters. Responsibility is one of the characters which could be developed through appropriate methods. This research was attempted to find out how the methods used to foster responsibility of temper tantrum children in Tahfidz learning at the Ar-Ruhama Islamic Foundation. This is a qualitative research. Data were gathered through observation, documentary study and interviews. Data analysis was conducted by referring to the theme. The results showed that the development of children's responsibility in the learning process was conducted by planning the routines, individual duties, planning the checklists, giving opportunities to lead, and giving rewards.
\end{abstract}

Keyword: temper tantrum; responsible; tahfidz learning.

Copyright (c) 2020 Monita Nur Shabrina, Nur Azizah, Muhammad Zuhad Rifqi

$\triangle$ Corresponding author:

Email Address : monitashabrina@gmail.com (Yogyakarta, Indonesia)

Received: 5 April 2020, Accepted: 14 April 2020, Published: 15 April 2020 


\section{PENDAHULUAN}

Masa kanak-kanak merupakan masa keemasan bagi setiap manusia atau biasa disebut golden age. Golden age yaitu masa ketika anak mempunyai banyak potensi yang sangat baik untuk dikembangkan. Pada tahap ini, menjadi waktu yang sangat tepat untuk menanamkan nilai-nilai kebaikan karakter yang nantinya diharapkan akan membentuk kepribadiannya (Yati \& Yaswinda, 2019). Anak usia dini adalah sekelompok individu yang berusia antara 0-8 tahun yang sedang berada dalam masa pertumbuhan dan perkembangan baik fisik maupun psikis anak usia dini berada pada tahap golden age periode kehidupan manusia (Islamiah, Fridani, \& Supena, 2019)

Usia dini merupakan fase pembentukan kepribadian yang tepat untuk ditanamkan nilai-nilai kebaikan ke dalam jiwa setiap anak (Taja, Inten, \& Hakim, 2019). Karakterkarakter yang ditanamkan pada anak usia dini akan tertanam dan menentukan kepribadian seseorang kelak ketika tumbuh dewasa. Munastiwi (Nuraeni, Andrisyah, \& Nurunnisa, 2019) juga berpendapat serupa bahwa pembentukan karakter berhubungan dengan dasar pembentukan sumber daya manusia yang berkualitas, dengan terwujudnya sumber daya berkualitas, yang pada akhirnya akan berkontribusi pada terwujudnya generasi beradab, berbudaya, cerdas spiritual dan intelektual, serta dapat bersaing secara global.

Pembentukan kepribadian seseorang harus sedini mungkin dilakukan dan butuh berbagai macam cara dan stimulasi untuk menumbuhkan karakter pada diri seorang anak. (Purwanti, 2016) berpendapat karakter yang sangat penting dikembangkan nilai-nilai etika seperti kepedulian, kejujuran, keadilan, tanggung jawab, dan rasa hormat terhadap diri dan orang lain bersama dengan nilai-nilai kinerja pendukungnya seperti ketekunan, etos kerja yang tinggi, kerja keras, dan kegigihan.

Kementerian Pendidikan Nasional (Yunus, 2015) menyebutkan ada 18 nilai-nilai dalam pendidikan karakter yaitu: 1) religius, 2) jujur, 3) toleransi, 4) disiplin, 5) kerja keras, 6) kreatif, 7) mandiri, 8) demokratis, 9) rasa ingin tahu, 10) semnagat kebangsaan, 11) cinta tanah air, 12) menghargai prestasi, 13) bersahabat/komunikatif, 14) cinta damai, 15) gemar membaca, 16) peduli lingkungan, 17) peduli sosial, 18) tanggung jawab.

Peneliti memilih salah satu karakter yang disebutkan oleh Kementrian Pendidikan Nasional yaitu karakter tanggung jawab karena penelitian mengenai tanggung jawab masih sangat sedikit. Penelitian tentang nilai karakter lebih banyak berfokus kepada disiplin (seperti: Sabartiningsih, Muzakki, \& Durtam, 2018; Tabi'in, 2017; Martsiswati, \& Suryono, 2014), dan kemandirian (Hewi, 2015; Dewanggi, Hastuti, \& Hernawati, 2012; Affrida, 2017). Tanggung jawab merupakan karakter yang penting untuk dibiasakan sejak dini. Tanggung jawab bagi anak usia dini bukanlah perkara yang mudah. Dibutuhkan lingkugan belajar yang nyaman dan aman bagi anak serta pembiasaan dan ketekunan dari orang tua dan pendidik (Haryani, Jaya \& Yulsyofriend, 2019). Tanggung Jawab adalah sifat dimana seseorang diharuskan menanggung dan menerima semua resiko atas apa yang ia lakukan. Hidayatullah (Arfiah \& Sumardjoko, 2017) juga berpendapat bahwa tanggung jawab merupakan kemampuan untuk mengambil keputusan yang rasional.

Ciri orang yang memiliki tanggung jawab adalah mampu melihat pilihan dan membuat keputusan atas dasar nilai serta norma-norma tertentu baik yang bersumber dari dalam dirinya maupun yang bersumber dari lingkungan (Hamalik, 1999) mau serta mampu melaksanakan tugas ataupun kewajibannya (Wibowo, 2012) berani, siap, dan teguh hatinya dalam menerima putusan dan tindakan yang dilakukan secara sengaja atau tidak sengaja, sadar mengambil keputusan dan mau menghadapi segala akibat yang terjadi, tidak akan lari dari situasi yang diakibatkan oleh perbuatannya dan mau menanggung akibat serta tidak menyalahkan orang lain

(Suparno, 2003) bisa menyelesaikan tugas-tugas tepat waktu, menghindari sikap ingkar janji, dan bisa mengerjakan tugas sampai selesai (Tafsir, 2011).

Karakter tanggung jawab dalam kehidupan memiliki banyak manfaat, diantaranya seseorang akan dipercaya, dihormati, dan disenangi oleh orang lain, sikap berani mengakui 
kesalahan (Haryani, Jaya, \& Yulsyofriend, 2019) hal tersebut sejalan dengan pendapat (Clarken, 2010) bahwa ada tiga manfaat jika dalam diri seseorang terdapat karakter tanggung jawab yang baik yaitu mampu mengendalikan diri, yang artinya memiliki tanggung jawab sebagai pribadi untuk menjalankan tugas semaksimal mungkin; mengakui kesalahan dan kegagalan, yaitu memiliki keberanian menanggung risiko atas kegagalan atau kesalahan dalam mengambil keputusan; dan memiliki kesungguhan dalam melayani orang lain.

Karakter tanggung jawab pada anak usia dini erat kaitannya dengan perkembangan sosial emosional. Wolfinger (Suyatno, 2005) menyebutkan ada empat aspek utama dalam perkembangan sosial emosional, salah satunya yaitu aspek pengembangan kebiasaan positif yang meliputi karakter tanggung jawab. Setiap anak memiliki fase perkembangan yang berbeda satu dengan lainnya tergantung bagaimana stimulasi dan dukungan yang ia dapatkan dari sekitarnya. Tidak jarang kita menemui anak yang mengalami hambatan atau masalah dalam proses perkembangannya. Salah satu masalah yang kerap ditemui pada anak dalam perkembangan sosial emosional terutama perkembangan emosionalnya adalah temper tantrum. (Potegal \& Davidson, 2003) melakukan penelitian pada 335 anak usia 18-60 bulan. Anak usia 18-24 bulan mengalami tantrum sebanyak $87 \%$, anak usia $30-36$ bulan paling banyak mengalami tantrum yakni sebanyak $91 \%$, dan usia $42-48$ bulan sebanyak $59 \%$.

Temper tantrum adalah masalah emosi yang paling umum terjadi pada anak usia dini. Menurut Davidson (Daniels, Mandleco, \& Luthy, 2012), temper tantrum didefinisikan sebagai episode ekstrim frustrasi atau kemarahan. Beberapa perilaku berhubungan dengan temperamen mengamuk pada balita dan anak-anak prasekolah termasuk berteriak, menjerit, menangis, jatuh ke lantai, memukul, menendang, melempar barang, dan menarik-menahan nafas yang panjang. Temper tantrum menurut Izati (Suzanti, et.al, 2015) adalah suatu letupan amarah anak yang sering terjadi pada saat anak menunjukan sikap negativistik atau penolakan, salah satu akibat jangka panjang bagi anak temper tantrum ketika dewasa adalah anak mempunyai kontrol diri yang rendah dan mudah marah.

Sedangkan menurut (Zakiyah, 2017) temper tantrum adalah episode dari kemarahan yang rata-rata digambarkan dengan perilaku menangis, berteriak, namun tantrum juga dikatakan sebagai luapan frustrasi yang ekstrim, yang tampak seperti kehilangan kendali seperti dicirikan oleh perilaku gerakan tubuh yang kasar atau agresif seperti membuang barang, berguling di lantai, membenturkan kepala, dan menghentakkan kaki ke lantai. Tantrum yang tidak diatasi menurut Dariyo (Zakiyah, 2017) dapat membahayakan fisik anak, selain itu anak tidak akan bisa mengendalikan emosinya atau anak akan kehilangan kontrol dan akan lebih agresif. Temper tantrum pada anak memiliki waktu atau durasinya masing-masing. Menurut (Astuti, 2012) biasanya, amarah memakan waktu 30 detik untuk 2 menit, dan intensitas tertinggi terjadi pada 30 detik pertama.

Yayasan Islam Ar-Ruhama ini terdiri dari 2 jenjang pendidikan yang pertama MI setingkat SD dan MTS setingkat SMP. Adapun kelas satu tingkat MI terdapat satu siswa berusia 6 tahun yang mengalami gangguan emosional temper tantrum. Dalam pelaksanaan pembelajaran sehari-harinya anak seringkali menunjukan perilaku tentrumnya tersebut. Biasanya perilaku tantrum yang ditunjukan sang anak adalah mudah marah, dan diekspresikan dengan perilaku menjerit-jerit, berteriak, berlari-lari tak tentu arah, tidak mengikuti aturan atau arahan dari guru, jahil kepada teman-temannya sehingga membuat temannya tersebut menangis, sulit memaafkan kesalahan teman dan enggan untuk meminta maaf. Penyebab anak mengidap tantrum dalam proses pembelajaran biasanya karena ada suatu hal yang tidak sesuai keinginannya. Adapun ungkapan tersebut dilakukan untuk mencari perhatian dari orang disekitar, adanya tekanan batin yang dia rasakan yang membuat emosinya memuncak

Temper tantrum yang terjadi pada anak biasanya terjadi karena beberapa penyebab baik yang datang dari dalam diri anak atau dari hal disekitarnya. Masalah yang biasa memicu anak menjadi tantrum adalah seperti perihal makan, tidur, berpakaian, konflik 
dengan saudara atau teman sebaya, atau frustasi karena sebuah objek (Potegal \& Davidson, 2003). Tetapi secara umum menurut (Astuti, 2012) masalah anak-anak disebabkan oleh kesalahan orang tua atau ketidaktahuan terhadap bagaimana berkomunikasi dan bagaimana untuk menyampaikan nilai-nilai yang baik untuk anak-anak.

Strategi dilakukan guru di Yayasan Islam Ar-Ruhama melakukan beberapa hal untuk mengetahui apa yang sebenarnya anak tersebut rasakan adalah dengan memposisikan diri menjadi teman bagi anak tersebut, mencoba mencari tahu apa yang anak tersebut inginkan, sehingga anak tersebut pada akhirnya bercerita bahwa ia merasa bahwa belajar merupakan hal yang melelahkan, tidak memiliki teman karena ia malu untuk bersosialisasi dengan teman-temannya, sehingga ia melakukan hal-hal seperti menjerit, berteriak, berlari, dsb., salah satunya karena untuk mencari perhatian dari teman-temannya, dan selalu dituntut oleh orangtuanya untuk melakukan hal yang tidak bisa ia lakukan. Hal tersebut sejalan dengan pendapat (Herawati, 2011) bahwa anak menjadi temper tantrum karena kebutuhan dasar akan kasih sayang dan rasa amannya tidak terpenuhi, sehingga perilaku anak menjadi menyimpang.

Anak akan mengalami peningkatan perkembangan pada usia emasnya, seperti pendapat (Anas, 2013) peningkatan perkembangan ini terjadi saat anak berusia 0-8 tahun, dan lonjakan perkembangan ini tidak akan terjadi lagi di periode selanjutnya. Seorang anak akan mencapai pertumbuhan dan perkembangan optimal jika kebutuhan dasarnya terpenuhi (Eliasa, 2011). Dalam menghadapi masa keemasan seorang anak orangtua harus terus meningkatkan kewaspadaan terhadap kemampuan anak untuk mengontrol keberhasilan peerkembangan dan keterampilannya, jika terjadi ketidak berhasilan dalam pengawasan pada perkembangan anak dapat menimbulkan perilaku negatif (Zakiyah, 2017). Perilaku negatif atau perilaku menyimpang dalam perkembangan sosial-emosional anak khususnya yang dikaji dalam penelitian ini adalah anak yang mengalami temper tantrum.

Perkembangan anak adalah suatu proses perubahan dimana anak belajar menguasai tingkat yang lebih tinggi dari berbagai aspek, khususnya proses perubahan perilaku sosial emosional anak memiliki karakternya tersendiri (Nadhirah, 2017) Perilaku dalam diri anak usia dini erat kaitannya dengan karakter pada anak tersebut. Karakter menurut Alwisol (Eliasa, 2011) diartikan sebagai gambaran tingkah laku yang menonjolkan nilai benar-salah, baik-buruk, baik secara eksplisit maupun implisit. Karakter dasar anak yang perlu dikembangkan sejak usia dini adalah karakter yang mempunyai nilai permanen yang bersifat absolut, Lickona (Arismantoro, 2008) menyebutnya sebagai "Golden Role", salah satu contoh dari "Golden Role" adalah tanggung jawab. Karakter dasar merupakan sifat fitrah manusia yang diyakini dapat dibentuk dan dikembangkan melalui metode-metode pendidikan tertentu (Andriani, 2012).

Pada anak temper tantrum membangun karakter diri memiliki tantangannya tersendiri, termasuk menumbuhkan karakter tanggung jawab. Jika membahas mengenai menanamkan karakter pada diri seorang anak terutama di sekolah, maka tidak akan lepas dari peran sebuah proses pembelajaran. Proses pembentukan karakter tanggung jawab pada anak dapat dilakukan melalui kegiatan yang terprogram yang dilakukan secara terus menerus dan pembiasaan. Salah satu program pembelajaran yang dilakukan secara continue di Yayasan Islam Ar-Ruhama adalah pembelajaran tahfidz. Karakter tanggung jawab memiliki peran penting pada diri seorang siswa yang mengikuti pembelajaran tahfidz. Karakter tanggung jawab dalam pembelajaran tahfidz merupakan bentuk rutinitas dalam mencapai target hafalan. Bentuk tanggung jawab siswa dalam pembelajaran tahfidz yaitu menghafal ayat al-qur'an (Kartika, 2019) dan menyetorkan hafalannya tersebut pada guru pembimbing.

Pembelajaran tahfidz di Yayasan Islam Ar-Ruhama ini wajib diikuti oleh seluruh siswa. Pembelajaran tahfidz di Yayasan Islam Ar-Ruhama ini merupakan salah satu program yang menjadi syarat untuk kelulusan kelak. Tahfidz al-qur'an dapat didefinisikan sebagai proses menghafal al-qur'an dalam ingatan sehingga dapat dilafalkan atau diucapkan diluar 
kepala secara benar dengan cara-cara tertentu secara terus menerus (Hidayah, 2016). Menghafal ayat al-qur'an membutuhkan metodenya tersendiri sebab metode mempunyai peranan penting dan sangat dibutuhkan. Dengan adanya metode akan dapat membantu seseorang untuk menentukan keberhasilan belajar menghafal al-qur'an dan meningkatkan hafalannya secara terprogram, Di samping juga diharapkan nantinya dapat membantu hafalan menjadi efektif (Akbar \& Hidayatullah, 2016).

Tahfidz Al-qur'an hendaknya dipandu dan dibimbing langsung oleh pemandu tahfidz yang berkompeten dalam penghafalan al-qur'an, supaya hafalan yang sudah didapatkan bisa dipantau dan dibina oleh pemandu tahfidz bila ada kesalahan dan sebagainya (Akbar \& Hidayatullah, 2016). Tahfidz erat kaitannya dengan karakter tanggung jawab karena dalam pembelajaran tahfidz tersebut ada beberapa indikator karakter tanggung jawab yang dikemukakan oleh (Kurniasih \& Sani, 2014) yang dibangun diantaranya melaksanakan tugas individu dengan baik, menerima resiko dan tindakan yang dilakukan, melaksanakan apa yang dikatakan tanpa disuruh atau diminta.

Dari kegiatan tahfidz yang dilakukan secara rutin dan tatap muka antara guru dan siswa dapat dijadikan media untuk menumbuhkan tanggung jawab pada siswa yang mengalami temper tantrum. Tujuan penelitian yaitu untuk mengetahui bagaimana cara yang digunakan untuk menumbuhkan karakter tanggung jawab pada anak temper trantrum melalui pembelajaran tahfidz. Berdasarkan penjelasan diatas peneliti ingin meneliti bagaimana metode pembelajaran tahfidz yang diberlakukan di MI Yayasan Islam ArRuhama dapat menumbuhkan karakter tanggung jawab pada anak temper tantrum.

\section{METODOLOGI}

Penelitian ini menggunakan pendekatan kualitatif. Penelitian kualitatif yaitu penelitian yang bermaksud untuk memahami fenomena tentang apa yang dialami oleh subjek penelitian misalnya perilaku, persepsi, dan persoalan tentang manusia yang diteliti (Moleong, 2006). Wujud dari pengolahan data berbentuk deskriptif atau penjelasan bukan hitungan angka. Kualitatif juga digunakan sebagai penafsiran fenomena yang terjadi menggunakan metode sesuai pilihan.

Metode yang digunakan untuk mengumpulkan data terdiri dari tiga cara, yaitu wawancara, observasi, dan dokumen. Wawancara dilakukan dengan cara semi terstruktur dengan guru pengampu mata pelajaran tahfidz Yayasan Islam Ar-ruhama. Selanjutnya dilakukan observasi untuk mengetahui proses pembelajaran dan hafalan tahfidz, materi yang digunakan, serta dokumen pendukung pembelajaran seperti RPPH, RPPM, dan dokumen evaluasi pembelajaran.

Teknik analisis data pada penelitian ini menggunakan cara reduksi data, penyajian data, dan kesimpulan atau verifikasi dengan membuat tema-tema . Terdapat lima tema yang muncul yaitu, a) rutinitas pembelajaran tahfidz, b) diberikannya tugas mandiri, c) adanya daftar ceklist (mutaba'ah), d) diberikan kesempatan memimpin, e) dan adanya bintang prestasi sebagai reward.

Adapun alur langkah kegiatan penelitian dampat dilihat pada bagan sebagai berikut :

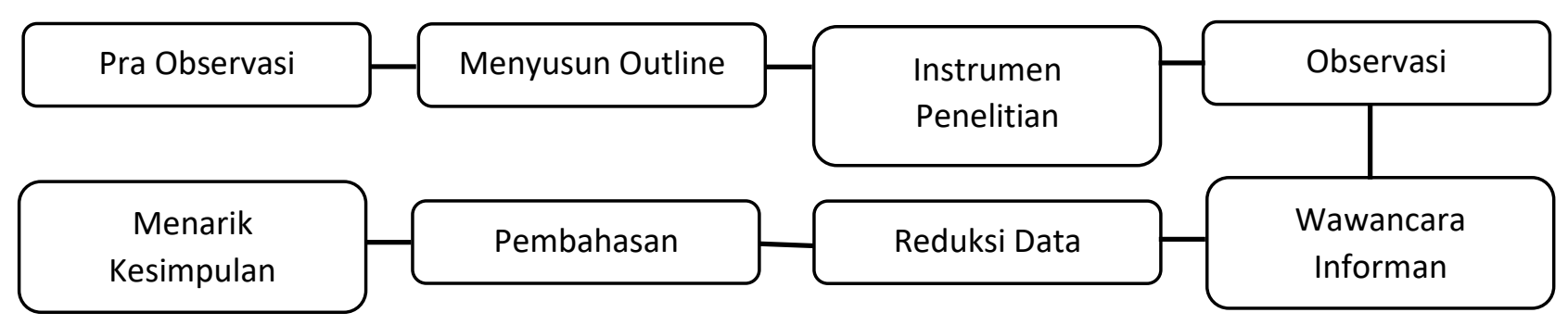

Bagan 1. Langkah Kegiatan Penelitian 


\section{HASIL DAN PEMBAHASAN}

Sekolah memiliki satu program pembelajaran yang diikuti oleh seluruh siswa di yayasan tersebut dan salah satu tujuan lain dari pembelajaran tersebut dapat dijadikan metode atau sarana dalam menumbuhkan sikap tanggung jawab pada anak tersebut. Pembelajaran yang dimaksud adalah pembelajaran tahfidz. Berikut adalah beberapa tema pembahasan tentang cara membangun sikap tanggung jawab pada anak temper tantrum melalui pembelajaran tahfidz:

\section{Rutinitas Pembelajaran Tahfidz}

Menumbuhkan karakter tanggungjawab pada anak usia dini khususnya pada anak yang mengalami temper tantrum dapat dilakukan dengan berbagai macam cara. Di MI Yayasan Islam Ar-ruhama salah satunya melalui rutinitas dalam pembelajaran tahfidz. Tahfidz yaitu menghafal sedikit demi seikit ayat-ayat al-qur'an yang telah dibaca berulangulang (Sa'dullah, 2008). Setiap anak termasuk anak yang mengalami temper tantrum ini telah mempunyai tugas hafalannya masing-masing yang rutin dihafalkan dan disetorkan setiap hari kepada guru pembimbing, (Hidayah, 2016) berpendapat juga bahwa ayat-ayat yang akan dihafal hendaknya disusun secara berkala dan bertahap setiap harinya.

Pembelajaran tahfidz di Yayasan Islam Ar-Ruhama dilaksanakan 5 kali dalam seminggu dengan durasi setiap pertemuannya yaitu 2 jam pelajaran atau 2 X 30 Menit, pembelajaran tahfidz ini relatif teratur yakni pada waktu setelah shalat dhuha dan sebelum jam istirahat pertama. Sebagaimana yang dikemukakan (Mustafa, 2016) pembelajaran tahfidz dilakukan rutin setiap minggunya, dan berupa kegiatan tatap muka secara individual antara guru dengan siswanya secara bergantian siswa yang satu dengan yang lainnya. Tatap muka antara guru dan siswa serta membaca langsung al-qur'an dihadapan seorang guru merupakan unsur penting dalam sistem pembelajaran tahfidz al-qur'an, sedang untuk menjaga kekuatan hafalan al-qur'an maka harus dilakukan pengulangan. Kegiatan rutin ini juga berkaitan dengan salah satu indikator menurut (Harmianto \& Muslim, 2015) yaitu melakukan tugas atau piket secara teratur, disini setiap anak secara rutin atau teratur melakukan setoran hafalan setiap harinya kepada guru pembimbing.

Dalam menghafalkan ayat-ayat al-qur'an dibutuhkan metode, Ahmadi dan Sholeh (Eko Hariyanti \& Marhumah, 2017) menjelaskan bahwa penggunaan metode yang tepat diperlukan dalam mengajarkan anak usia dini menghafal al-qur'an. Dengan memanfaatkan daya ingat anak yang masih baik, guru dapat menggunakan beberapa metode menghafal alqur'an pada anak usia dini (Lubis \& Ismet, 2019). Banyak metode yang dapat digunakan dalam menghafal al-qur'an, sebagaimana yang dikemukakan (Susianti, 2016) metode menghafal al-qur'an pada umumnya terdiri dari dua cara yaitu dengan cara menambah hafalan baru dan mengulang hafalan yang telah ada. Semakin berkembangnya zaman banyak modifikasi-modifikasi metode menghafal al-qur'an yang dapat digunakan, salah satunya metode "A $B a T a T s a$ " yang digunakan oleh yayasan Ar-Ruhama ini. Metode ini dilakukan guna memudahkan dan meningkatkan kemampuan membaca dan menghafal ayat Al-qur'an. Kegiatan yang dilakukan oleh guru tahfidz disini adalah memberikan motivasi kepada seluruh peserta didik secara berkesinambungan, mengajarkan cara bacaan dan irama membaca atau menghafal ayat al-qur'an. 


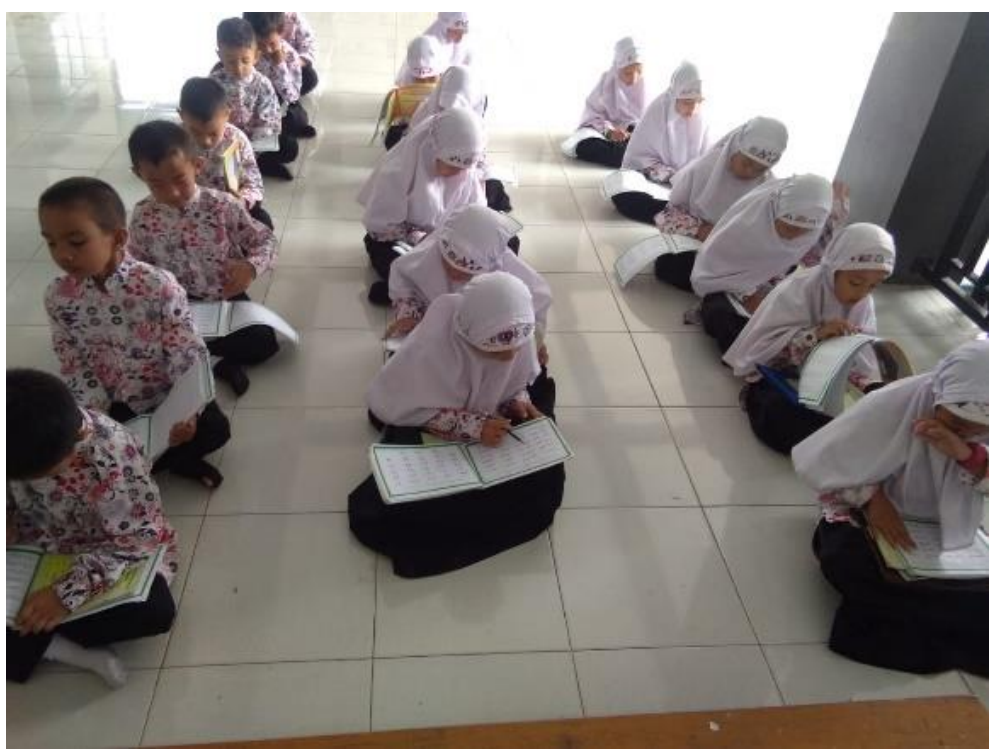

\section{Tugas Mandiri}

\section{Gambar 1. Rutinitas Pembelajaran Tahfidz}

Pembelajaran tahfidz memberikan tugas mandiri untuk masing-masing anak, termasuk juga untuk anak yang mengalami temper tantrum, tidak ada perbedaan tugas dengan siswa normal lainnya. Tugas mandiri pertama yang harus dilakukan yaitu, dalam setiap pertemuan siswa masing-masing ditugaskan untuk membaca 10 kali ayat atau surat al-qur'an yang sedang dihafalkan, kemudian mengulang kembali hafalan ayat atau surat yang sedang dihafal secara terus menerus hingga siswa hafal dan paham dengan bacaan hafalannya masing-masing atau yang biasa disebut "Murajaah". Hal ini seperti yang dikemukakan (Rusadi, 2018) Murajaah adalah kegiatan mengulang-ulang hafalan al'qur-an.

Setelah dirasa hafal dan paham dengan ayat yang dihafalkan maka tugas yang kedua yang harus dilakukan siswa adalah menyetorkan hafalan tersebut kepada guru pengampu. Metode yang digunakan dalam pembelajaran tahfidz di Yayasan Islam Ar-Ruhama ini adalah metode "Talaqqi". Metode talaqqi adalah menyetorkan atau memperdengarkan hafalan yang baru dihafal kepada seorang guru atau instruktur. Talaqqi dilakukan dengan berhadapan langsung antara siswa dan guru dengan posisi tenang dan nyaman, mengulangulang ayat sampai benar-benar hafal (Kartika, 2019) atau bahasa sederhananya adalah tatap muka (Hidayah, 2016). Proses talaqqi ini dilakukan untuk mengetahui hasil hafalan dan mendapatkan bimbingan seperlunya (Sa'dullah, 2008).

Tugas mandiri ketiga yang diberikan kepada siswa untuk dilaksanakan ketika di rumah yaitu mendengarkan murottal al-qur'an. Mendengarkan murottal yaitu mendengarkan rekaman bacaan al-qur'an baik dari CD murottal qari' terkenal (Hidayah, 2018) atau rekaman bacaan al-qur'an yang dilantunkan oleh seorang qari' atau pembaca alqur'an dengan tempo yang lambat serta dibacakan dengan baik dan benar. Ini dilakukan berulang-ulang sehingga anak hafal diluar kepala ayat yang sedang dihafalkannya dan mendengarkan murottal juga mengajarkan anak menghafal secara mandiri ketika sedang tidak ada bimbingan dari gurunya atau ketika anak sedang berada di rumah.

Peran orangtua berpengaruh besar bagi kesuksesan anak dalam menghafal terutama bagi anak yang mengalami temper tantrum ini harus mendapatkan pengawasan lebih ekstra dari orangtua di rumah, karena orantua adalah pembimbing dan pengontrol utama di rumah (Hidayah, 2016). (Djamarah, 2004) mengatakan bahwa sesungguhnya mendidik anak adalah tanggungjawab orangtua. Adanya tugas mandiri juga sejalan dengan salah satu indikator tanggung jawab yang dikemukakan oleh (Kurniasih \& Sani, 2014) yaitu melaksanakan tugas individu dengan baik, dalam hal ini yaitu mendengarkan murottal dan murajaah. 


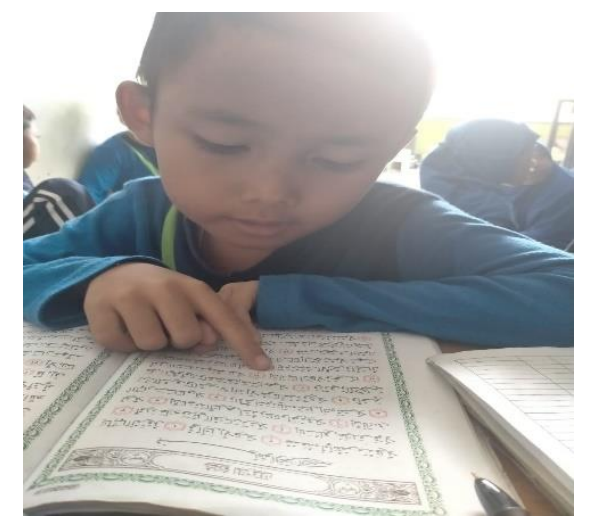

Gambar 2. Kegiatan Talaqqi

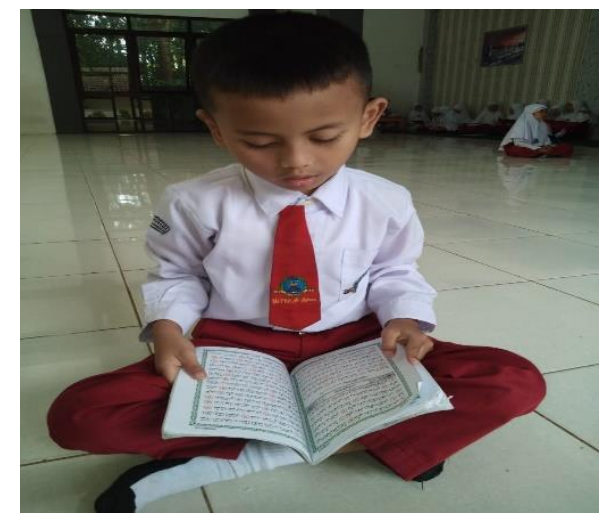

Gambar 3. Kegiatan Muraja'ah

\section{Daftar Ceklist (Mutaba'ah)}

Hal lain yang dilakukan rutin untuk menstimulus sikap tanggung jawab anak tantrum dan sesuai dengan indikator tanggung jawab menurut (Harmianto \& Muslim, 2015) yaitu membuat laporan setiap kegiatan yang dilakukan dalam bentuk lisan maupun tulis, adalah dengan memberikan anak tabel ceklist hafalan, solat, mengaji, dan ibadah lainnya yang harus diisi setiap harinya, atau yang biasa "Mutaba'ah". Mutaba'ah adalah strategi pemantauan agar guru bisa melakukan pengecekan rutinitas ibadah dalam bentuk rapor (Yulianto, 2016), hal itu didukung dengan pendapat (Sholihan, 2017) bahwa mutaba'ah adalah sebuah hasil dari pikiran tentang evaluasi suatu program yang hasilnya itu terwujud dalam sebuah karya berupa lembaran-lembaran yang disusun menjadi satu kesatuan.

Yayasan islam Ar-Ruhama membuat mutaba'ah dengan cara membentuk buku dan melakukan pengecekan oleh guru pembimbing setiap harinya guna dilakukan penilaian dan evaluasi. Selain sebagai alat controlling bagi guru, mutaba'ah juga menjadi alat controlling untuk orangtua yang harus dicek dan diparaf setiap harinya, ini sejalan dengan pendapat (Hidayah, 2016) buku mutaba' ah selama di rumah yang harus ditandatangani oleh orangtua. Dari diberikannya tabel ceklist harian tersebut sikap tanggung jawab anak akan terpacu setiap harinya, karena anak akan memiliki rasa tanggung jawab atas laporan tugas-tugas ibadahnya. Adanya tabel ceklist ini juga akan melatih kejujuran anak dalam mengisi laporan tersebut.

Demi kelangsungan laporan kegiatan harian ini menurut (Sayyid, 2013) orangtua harus memiliki komitmen untuk menghadirkan anak selalu tepat waktu dan giat dalam menghafal, orantua harus memberikan pengawasan terhadap anaknya dengan mengontrol buku mutaba'ah anak setiap harinya. Kerjasama harus terjalin antara kedua orangtua dengan pihak guru pembimbing guna menyempurnakan seluruh kegiatan yang dilakukan oleh anak (Lubis \& Ismet, 2019). Dengan adanya mutaba'ah ini juga orangtua dapat membimbing anaknya yang mengalami temper tantrum agar lebih bertanggung jawab atas hafalan dan kegiatan ibadah lainnya di rumah, dan juga melatih anak tersebut agar lebih bertanggung dan teratur dalam mengisi mutaba'ahnya.
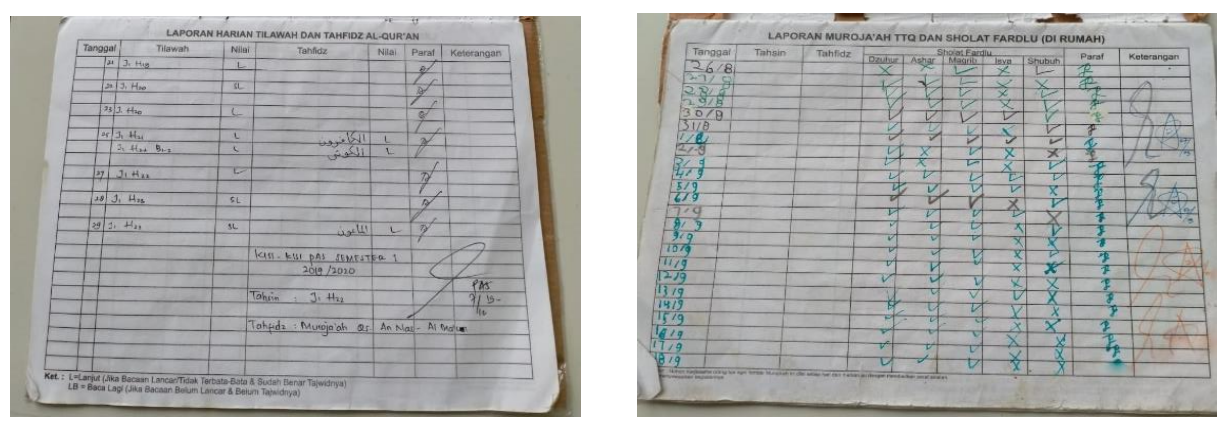

Gambar 4 dan 5. Buku Mutaba'ah 


\section{Kesempatan Memimpin}

Upaya untuk menumbuhkan karakter tanggung jawab pada anak temper tantrum selanjutnya adalah dengan memberikan anak tersebut kepercayaan atau amanah menjadi ketua kelompok belajar, bahkan menjadikan anak tersebut pemimpin kelas agar sikap tanggung jawab pada anak tersebut semakin terbangun karena kepercayaan yang gurunya dan teman-temannya berikan kepadanya menjadikan anak tersebut penanggung jawab kelas saat setoran hafalan sedang berlangsung. Sikap tanggung jawab dapat dilihat pada diri anak ketika diberi kesempatan untuk memimpin, selain munculnya sikap tanggung jawab rasa percaya diri dalam anak tersebut juga akan ikut berkembang. Anak yang membutuhkan penanganan khusus dalam hal ini adalah anak yang mengalami temper tantrum juga memiliki hak untuk memperoleh kesempatan yang sama dalam mengembangkan kemampuan memimpin sebagaimana kesempatan yang diberikan kepada anak normal (Sari \& Suwanda, 2014).

Diberikannya kesempatan memimpin ini juga merupakan sebuah bentuk interaksi sosial antara invidu dengan kelompok yang menurut (Pebriana, 2017) jenis interaksi ini saling berhadapan dalam bentuk berkomunikasi antara satu individu dengan kelompok. Interaksi sosial tersebut juga akan menumbuhkan atau menstimulus sikap tanggung jawab anak ketika memimpin kelompok atau kelasnya ketika berlangsungnya kegiatan belajar mengajar berlangsung. Dengan diberikannya kesempatan untuk memimpin anak sudah melaksanakan salah satu indikator tanggung jawab sesuai yang dikemukakan (Harmianto \& Muslim, 2015) yaitu peran serta aktif dalam kegiatan, hal ini sejalan dengan pendapat (Arsyad, 2014) Guru memberikan kesempatan pada siswa berpartisipasi aktif agar siswa merasa lebih bersemangat dalam belajar dan membuat anak tersebut betah mengikuti pembelajaran dan tidak mudah bosan di kelas.

Peran serta anak dalam kegiatan ini terlatih juga kemampuan sosial emosionalnya, sejalan dengan pendapat (Sukino \& Muttaqin, 2019) pembelajaran tahfidz juga dapat melatih kemampuan mengontrol emosi (agresifitas) anak dalam kehidupan sosialnya dapat mengendalikan diri untuk tidak mudah marah ketika ada hal yang berjalan tidak sesuai dengan kehendaknya.

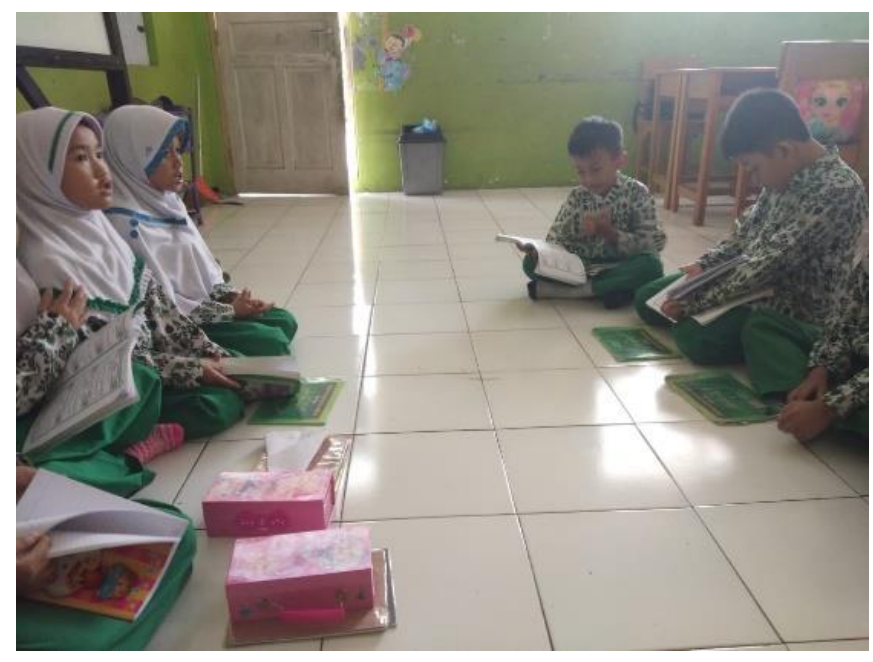

Gambar 6. Anak Memimpin Kegiatan Berdo'a Bersama

\section{Bintang Prestasi}

Langkah terakhir yang dilakukan di Yayasan Islam Ar-ruhama dalam menumbuhkan tanggung jawab anak temper tantrum melalui pembelajaran tahfidz tersebut yaitu dengan memberikan tantangan hafalan agar bisa mengejar target, dan setelah anak bisa mencapai target tersebut guru memberikan apresiasi dalam bentuk bintang prestasi. Dimana sebelumnya sang anak belum pernah mendapatkan bintang prestasi tersebut. Setelah sekali 
mendapatkan bintang prestasi tersebut anak sangat antusias, dan dimoment tersebut guru membuat kesepakatan dengan anak tersebut perihal target dan tanggung jawab hafalannya. Perlahan-lahan anak tersebut dapat memahami dan menyetujui kesepakatan yang dibuat oleh guru tahfidznya tersebut. Guru juga tidak lupa selalu mengapresiasi saat anak tersebut berbuat baik, hafalannya bertambah, dan selalu memotivasi anak tersebut agar bisa bertanggung jawab atas hafalan-hafalan dan seluruh tugasnya, itu semua juga termasuk dari indikator tanggung jawab menurut (Kurniasih \& Sani, 2014) menerima resiko atas tindakan yang dilakukan, dalam hal ini adalah reward atau langkah apresiasi atas pencapaian tugas sang anak.

Hal diatas selaras dengan pendapat (Sabartiningsih, Muzakki, \& Durtam, 2018) reward adalah salah satu cara yang dilakukan untuk memberikan suatu penghargaan kepada seseorang karena sudah mengerjakan suatu hal yang benar, sehingga seseorang itu bisa semangat lagi dalam mengerjakan tugas tertentu dan lebih termotivasi dalam melakukan sesuatu hal yang lainnya serta lebih baik prosesnya sehingga seseorang tersebut mampu mencapai keberhasilan dari suatu hal yang ia kerjakan, hal ini diperkuat oleh pendapat (Hapsari \& Christiana, 2013) upaya yang dilakukan agar anak dapat belajar dengan menyenangkan yaitu dengan memberikan reward, serta pendapat dari (Uno, 2007) bahwa salah satu teknik motivasi yang dapat dilakukan dalam pembelajaran adalah dengan memberikan penghargaan.

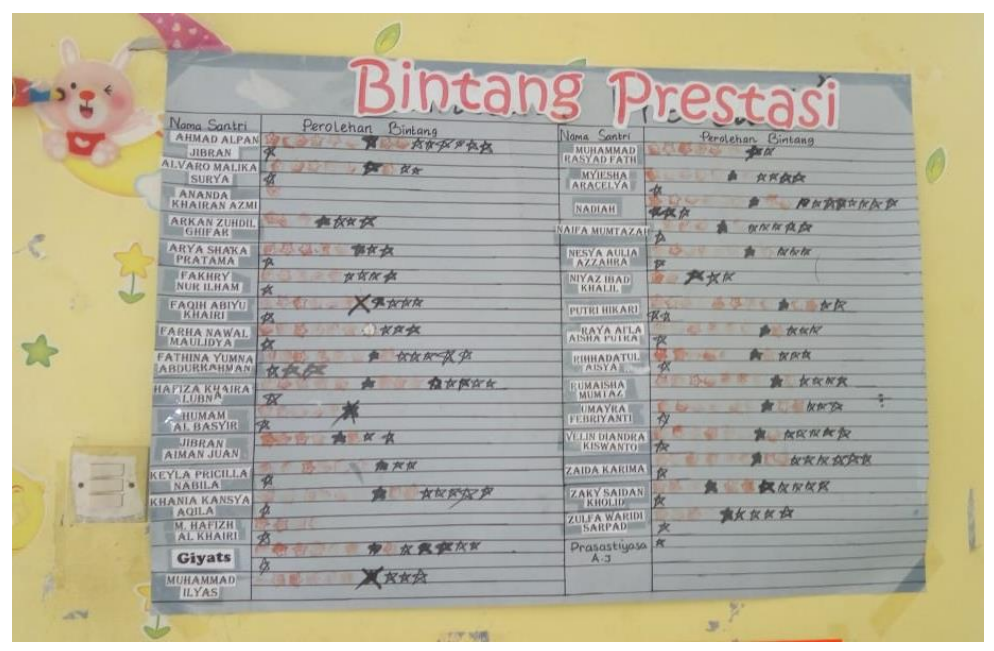

Gambar 7. Papan Bintang Prestasi

\section{SIMPULAN}

Metode pembelajaran tahfidz memberikan andil dalam membangun sikap atau karakter tanggung jawab pada anak yang mengalami temper tantrum di MI Yayasan Islam Ar-Ruhama. Dari pembelajaran tahfidz tersebut dapat menstimulus sikap tanggung jawab dengan beberapa cara yakni rutinitas pembelajaran tahfidz, diberikannya tugas mandiri, adanya daftar ceklist (mutaba'ah), diberikan kesempatan memimpin, dan adanya bintang prestasi sebagai reward. Pembelajaran tahfidz ini juga mendidik siswa tantrum tersebut menjadi lebih kondusif dalam mengikuti kegiatan belajar mengajar serta dapat mengontrol luapan emosinya.

\section{UCAPAN TERIMAKASIH}

Dengan selesainya penelitian ini penulis mengucapkan terimakasih kepada guru tahfidz dan seluruh staff Yayasan Islam Ar-Ruhama Kabupaten Kuningan yang telah membantu penulis untuk mendapatkan informasi guna menyelesaikan penelitian yang dilakukan sehingga penelitian ini dapat terlaksana dengan baik, lancar, dan sukses. 


\section{DAFTAR PUSTAKA}

Affrida, E. N. (2017). Strategi Ibu dengan Peran Ganda dalam Membentuk Kemandirian Anak Usia Pra Sekolah. Jurnal Obsesi : Jurnal Pendidikan Anak Usia Dini, 1(2), 114. https://doi.org/10.31004/obsesi.v1i2.24

Akbar, A., \& Hidayatullah, H. (2016). Metode Tahfidz Al-Qur'an Di Pondok Pesantren Kabupaten Kampar. Jurnal Ushuluddin, 24(1), 91. https://doi.org/10.24014/jush.v24i1.1517

Anas, M. (2013). Psikologi Menuju Aplikasi Pendidikan. Pustaka Education.

Andriani, T. (2012). Permainan Tradisional Dalam Membentuk Karakter Anak Usia Dini. Jurnal Sosial Budaya, 9(1), 121-136. https://doi.org/http://dx.doi.org/10.24014/sb.v9i1.376

Arfiah, S., \& Sumardjoko, B. (2017). Penguatan Karakter Tanggung Jawab dan Kemandirian pada Mahasiswa PPKN Melalui Perkuliahan Kepramukaan dalam Upaya Mempersiapkan Mutu Lulusan Sebagai Pembina Ekstrakurikuler di Sekolah. Jurnal $\begin{array}{llll}\text { Pendidikan Ilmu } & \text { Sosial, } & \text { 76-92. }\end{array}$ https:/ / doi.org/https:/ / doi.org/10.2317/jpis.v27i2.5721

Arismantoro. (2008). Tinjauan Berbagai Aspek Character Building; Bagaimana Mendidik Anak Berkarakter. Tiara Wacana.

Arsyad, A. R. (2014). Religious Education for Special Need Learners at SMPLB, the Center of Special Needs Education and Special Education Services. Al Qalam; Jurnal Penelitian $\begin{array}{llll}\text { Agama Dan Sosial } & \text { Budaya, 161-170. }\end{array}$ https://doi.org/http://dx.doi.org/10.31969/alq.v20i1.168

Astuti, H. P. (2012). the Role of Hypnoparenting in the Treatment of Early Childhood'S Temper Tantrum. Indonesian Journal of Early Childhood Education Studies, 1(1), 26-31. https://doi.org/10.15294/ijeces.v1i1.9200

Clarken, R. (2010). Considering Moral Intelligence. As Part of A Holistic Education. Northern Michigan University.

Daniels, Elizabeth., Mandleco, Barbara., Luthy, K. E. (2012). Assessment, management, and prevention of childhood temper tantrums. Journal of the American Academy of Nurse Practitioners, 24(10), 569-573. https:// doi.org/10.1111/j.1745-7599.2012.00755.x

Dewanggi, Mustika. Hastuti, Dwi., Hernawati, N. (2012). Pengasuhan Orang Tua dan Kemandirian Anak Usia 3-5 Tahun berdasarkan Gender di Kampung Adat Urug. In Jurnal Ilmu Keluarga dan Konsumen (Vol. 5, Issue 1, pp. 19-28). https:/ / doi.org/10.24156/jikk.2012.5.1.19

Djamarah, S. B. (2004). Pola Komunikasi Orang Tua dan Anak dalam Keluarga. PT. Rineka Cipta.

Eko Hariyanti, W., \& Marhumah. (2017). Indonesian Journal of Islamic Early Childhood Education Association of Indonesian Islamic Kindergarten Teachers Education Study Program Method of Memorizing the Qur'an In Early Childhood Period (Case Studies in TKIT Yaa Bunayya and RA Darussalam Yogyakart. Indonesian Journal of Islamic Early Childhood Education, 2(1), 89-98.

Eliasa, E. I. (2011). Pentingnya Kelekatan Orangtua dalam Internal Working Model untuk Pembentukan Karakter Anak. Developmental Psychology, 33(5), 806-821.

Hapsari, R. P., \& Christiana, E. (2013). Studi Tentang Pelaksanaan Pemberian Reward Dalam Meningkatkan Motivasi Belajar Kelompok-a Di Tk Islam Al-Azhar 35 Surabaya Study Councering the Implemetation of Reward in Increasing Motivation for Learning Group-a in Al-Azhar 35 Islamic Kindergarten 35 Su. Jurnal BK Unesa, 04.

Harmianto, S., \& Muslim, A. H. (2015). Hasil-hasil Penelitian dan Pengabdian LPPM Universitas Muhammadiyah Purwokerto. In Seminar Nasional.

Haryani, Retno Ika., Jaya, I., \& Yulsyofriend. (2019). Pembentukan karaker tanggung jawab di taman kanak-kanak Islam Budi Mulia Padang. Jurnal Ilmiah Potensia, 4(2), 105-114. https://doi.org/https://doi.org/10.33369/jip.4.2.105-114 
Herawati, N. I. (2011). Menghadapi Anak Usia Dini yang Temper Tantrum. Cakrawala Dini: $\begin{array}{llllll}\text { Jurnal Pendidikan Anak Usia Dini, Vol } & \text { (2012)). }\end{array}$ https:// doi.org/https:// doi.org/10.17509/cd.v3i2.10338

Hewi, L. A. (2015). Kemandirian usia dini di suku bajo. Jurnal Pendidikan Usia Dini, 9(1), 76. https:// doi.org/https:// doi.org/10.21009/JPUD.091

Hidayah, A. (2018). Metode Tahfidz Al-Qur'an Untuk Anak Usia Dini (Kajian Atas Buku Rahasia Sukses 3 Hafizh Quran Cilik Mengguncang Dunia). Jurnal Studi Ilmu-Ilmu AlQur'an Dan Hadis, 18(1), 51. https:/ / doi.org/10.14421/qh.2017.1801-04

Hidayah, N. (2016). Strategi Pembelajaran Tahfidz Al-Qur'an di Lembaga Pendidikan. Ta'allum: Jurnal Pendidikan Islam, 4(1), 63-81. https:/ / doi.org/10.21274/taalum.2016.4.1.63-81

Islamiah, Fajriyatul., Fridani, Lara., Supena, A. (2019). Konsep Pendidikan Hafidz Qur'an pada Anak Usia Dini. Jurnal Obsesi: Jurnal Pendidikan Anak Usia Dini, 3(1), 30. https:// doi.org/10.31004/obsesi.v3i1.132

Kartika, T. (2019). Manajemen Pembelajaran Tahfidz Al-qur'an Berbasis Metode Talaqqi. Islamic, Jurnal Manajemen, Education, 4(2), 245-256. https:/ / doi.org/DOI :10.15575/isema.v4i2.5988

Kurniasih, I., \& Sani, B. (2014). ImplementasiKurikulum 2013: Konsep dan Penerapan. Kata Pena.

Lubis, A. M., \& Ismet, S. (2019). Metode Menghafal Alquran Pada Anak Usia Dini di Tahfidz Center Darul Hufadz kota Padang. Aulad: Journal on Early Childhood, 2(2), 8-14. https:/ / doi.org/10.31004/aulad.v2i2.30

Martsiswati, Ernie., Suryono, Y. (2014). Peran Orang Tua Dan Pendidik Dalam Menerapkan Perilaku Disiplin Terhadap Anak Usia Dini. Jurnal Pendidikan Dan Pemberdayaan Masyarakat, 1(2), 187. https://doi.org/10.21831/jppm.v1i2.2688

Moleong, J, L. (2006). Metodologi Penelitian Kualitatif. PT. Remaja Rosdakarya.

Mustafa, M. S. (2016). Pelaksanaan Metode Pembelajaran Tahfizh Al-Qur'an Di Madrasah Tahfidz Al-Qur'an Al-Imam 'Ashim Tidung Mariolo, Makassar. Al-Qalam, 18(2), 245. https:/ / doi.org/10.31969/alq.v18i2.73

Nadhirah, Y. F. (2017). Perilaku Ketidakmatangan Sosial-Emosional Pada Anak Usia Dini. 2(1), 5974.

Nuraeni, Lenny., Andrisyah, Andrisyah., Nurunnisa, R. (2019). Efektivitas Program Sekolah Ramah Anak dalam Meningkatkan Karakter Anak Usia Dini. Jurnal Obsesi : Jurnal Pendidikan Anak Usia Dini, 4(1), 20. https:// doi.org/10.31004/obsesi.v4i1.204

Pebriana, P. H. (2017). Jurnal Obsesi: Jurnal Pendidikan Anak Usia Dini Analisis Penggunaan Gadget terhadap Kemampuan Interaksi Sosial. Jurnal Pendidikan Anak Usia Dini, 1(1), 8. https:/ / doi.org/10.31004/obsesi.v1i1.26

Potegal, M., \& Davidson, R. J. (2003). Temper tantrums in young children: 1. Behavioral composition. Journal of Developmental and Behavioral Pediatrics, 24(3), 140-147. https:// doi.org/10.1097/00004703-200306000-00002

purwanti, eri. (2016). Implementasi penggunaan ssp (. TERAMPIL Jurnal Pendidikan Dan $\begin{array}{lll}\text { Pembelajaran } \quad \text { Dasar, } & \text { 3(2), }\end{array}$ https:// doi.org/https:// doi.org/10.24042/terampil.v3i2.1194

Rusadi, B. E. (2018). Implementasi Pembelajaran Tahfiz Al-Quran Mahasantri Pondok Pesantren Nurul Quran Tangerang Selatan. Intiqad: Jurnal Agama Dan Pendidikan Islam, 10(1), 162-173. https://doi.org/10.30596/intiqad.v10i1.1920

Sa'dullah. (2008). Cara Praktis Menghafal Al-Qur'an. Dema Insani.

Sabartiningsih, Mila., Muzakki, Jajang Aisyul., Durtam, D. (2018). Implementasi Pemberian Reward Dan Punishment Dalam Membentuk Karakter Disiplin Anak Usia Dini. AWLADY: Jurnal Pendidikan Anak, 60. https:// doi.org/10.24235/awlady.v4i1.2468

Sari, A. J., \& Suwanda, I. M. (2014). Implementasi Pendidikan Demokrasi Pada Anak Berkebutuhan Khusus Tunarungu Di Smalb-B Pgri Dlanggu I Made Suwanda. Kajian 
DOI: $10.31004 /$ obsesi.v4i2.511

Moral Dan Kewarganegaraan, 03, 1046-1059.

Sayyid, S. A. (2013). Balita pun Hafal Al-Qur'an. PT Tiga Serangkai Pustaka Mandiri.

Sholihan, N. (2017). Monitoring Aktivitas Tilawah Al-Qur'an Melalui Buku Mutaba'ah Siswa Di Smp It Nur Hidayah Surakarta Tahun AjaraN 2016/2017. Institut Agama Islam Negeri Surakarta.

Sukino, \& Muttaqin, I. (2019). Penguatan Akhlak Mulia dalam Pembelajaran Tahfidz AlQur'an di MTs Ma'arif Binjai Hulu Sintang (Perspektif Rekonstruksi Sosial). In Ta'allum: Jurnal Pendidikan Islam (Vol. 7, Issue 1). https://doi.org/10.21274/taalum.2019.7.1.125-156

Suparno, P. (2003). Pendidikan Budi Pekerti untuk SMU-SMK. Kanisius.

Susianti, C. (2016). Efektivitas Metode Talaqqi Dalam Meningkatkan Kemampuan Menghafal Al-Qur'an Anak Usia Dini. Tunas Siliwangi Halaman, 2(1), 1-19. https://doi.org/https:// doi.org/10.22460/ts.v2i1p1-19.305

Suyatno. (2005). Konsep Dasar Anak Usia Dini. Departemen Pendidikan Nasional.

Suzanti, Marsella Wahyu., Riyani, Enggar., Istiqomah, A., Ihtiar, C. (2015). Efektivitas Finger Painting untuk Menurunkan Perilaku Temper Tantrum Pada Anak KB PK Yogyakarta. In Jurnal Pendidikan Anak (Vol. 3, Issue 1). https://doi.org/https://doi.org/10.21831/jpa.v3i1.3055

Tabi' in, A. (2017). Pengelolaan Pendidikan Karakter Disiplin Anak Usia Dini Studi Kasus Di Al-Muna Islamic Preschool Semarang. AWLADY: Jurnal Pendidikan Anak, 3(1). https://doi.org/10.24235/awlady.v3i1.989

Tafsir, A. (2011). Pendidikan Karakter Perspektif Islam. Rosda.

Taja, Nadri., Inten, Dinar Nur., Hakim, A. . (2019). Upaya Meningkatkan Keterampilan Mengajar Baca Tulis Al-Qur`an bagi Guru. Jurnal Obsesi : Jurnal Pendidikan Anak Usia Dini, 3(1), 68. https:// doi.org/10.31004/obsesi.v3i1.135

Uno, H. B. (2007). Teori Motivasi dan Pengukurannya. Bumi Aksara.

Wibowo, A. (2012). Pendidikan Karakter Usia Dini (Strategi Membangun Karakter Usia Dini). Pustaka Belajar.

Yati, F., \& Yaswinda, Y. (2019). Penerapan Model Evaluasi CIPPO dalam Mengevaluasi Penyelenggaraan Lembaga PAUD. Jurnal Obsesi: Jurnal Pendidikan Anak Usia Dini, 4(1), 30. https://doi.org/10.31004/obsesi.v4i1.238

Yulianto, A. (2016). Pendidikan Ramah Anak Studi Kasus SDIT Nur Hidayah Surakarta. AtTarbawi: Jurnal Kajian Kependidikan Islam, 1(2), 137. https://doi.org/10.22515/attarbawi.v1i2.192

Yunus, M. (2015). Upaya Guru Membentuk Karakter Bangsa Pada Anak Usia Dini Melalui Proses Pembelajaran Di Yayasan Raudatul Athfal (RA) Fathun Qarib. Serambi Akademica, III(2), 174-182. https:/ / doi.org/http://dx.doi.org/10.32672/jsa.v7i2

Zakiyah, N. (2017). Hubungan Pola Asuh Orang Tua Dengan Kejadian Temper Tantrum Pada Usia Toddler Di Dukuh Pelem Kelurahan Baturetno Banguntapan Bantul. Interest : Jurnal Ilmu Kesehatan, 6(1), 62-71. https://doi.org/10.37341/interest.v6i1.83 